\title{
O USO DE METODOLOGIAS ATIVAS NO PROGRAMA NACIONAL DE INTEGRAÇÃO DA EDUCAÇÃO PROFISSIONAL COM A EDUCAÇÃO BÁSICA NA MODALIDADE DE EDUCAÇÃO DE JOVENS E ADULTOS (EJAEPT)
}

\author{
THE USE OF ACTIVE METHODOLOGIES IN THE NATIONAL PROGRAM OF \\ INTEGRATION OF PROFESSIONAL EDUCATION WITH BASIC EDUCATION IN \\ THE MODALITY OF YOUTH AND ADULT EDUCATION (EJAEPT)
}

\section{EL USO DE METODOLOGÍAS ACTIVAS EN EL PROGRAMA NACIONAL DE INTEGRACIÓN DE LA EDUCACIÓN PROFESIONAL CON LA EDUCACIÓN BÁSICA EN EL MODO DE EDUCACIÓN DE JÓVENES Y ADULTOS (EJAEPT)}

\author{
Clarissa Barretta \\ Titulação do autor: Mestre em Ciência dos Alimentos \\ Instituição: Instituto Federal de Santa Catarina \\ E-mail: clarissa.vet@hotmail.com \\ Priscila Juliana da Silva \\ Titulação do autor: Mestre em Educação \\ Instituição: Instituto Federal de Santa Catarina \\ E-mail: priscila.silva@ifsc.edu.br

\section{Luiz Álvaro Monteiro Júnior} \\ Titulação do autor: Doutor em Medicina Veterinária \\ Instituição: Instituto Federal Catarinense \\ E-mail: luiz.monteiro@ifc.edu.br
}

\section{RESUMO}

Este artigo tem por objetivo geral analisar as dificuldades e potencialidades do desenvolvimento de metodologias ativas no Programa Nacional de Integração da Educação Profissional com a Educação Básica na Modalidade de Educação de Jovens e Adultos (EJAEPT). Esse estudo foi desenvolvido com duas turmas do Curso Técnico em Agroindústria ofertado no Campus Camboriú do Instituto Federal Catarinense (IFC). Assim, definiu-se a abordagem dessa pesquisa como qualitativa e realizaram-se observações participantes de atividades pedagógicas desenvolvidas com duas turmas. As anotações e relatos dessas observações foram organizadas para realização da análise documental. Concluiu-se que o perfil dos estudantes das turmas A e B exigiu estratégias de ensino-aprendizagem diferentes, bem como tempos e ritmos de ensino-aprendizagem distintos. Nesse processo de docência com ambas as turmas, observa-se que as dificuldades de aprendizagem aparecem atreladas à dificuldade de visualizar os conhecimentos teóricos na prática. Nesse sentido as metodologias ativas possibilitaram que se estabelecesse a relação entre teoria e prática tornando a aprendizagem significativa.

Palavras-chave: Educação Profissional e Tecnológica. EJAEPT. Aprendizagem. 
Metodologias Ativas.

\begin{abstract}
This article aims to analyze the difficulties and potentialities of the development of active methodologies in the National Program for the Integration of Professional Education with Basic Education in the modality of Youth and Adult Education (EJAEPT). The study, which falls within the qualitative approach, was carried out with two groups taking the Technical course in Agroindustry offered at Instituto Federal Catarinense (IFC), Camboriú campus. Data was generated through participant observations of the pedagogical activities developed with the two groups and both notes and reports of these observations were organized to carry out the documentary analysis. It was concluded that the profile of students in groups A and B required different teaching-learning strategies, as well as different teaching-learning times and rhythms. It could also be noticed during the teaching process with the groups that learning difficulties seems to be linked to the difficulty of visualizing theoretical knowledge in practice. In this sense, the active methodologies allowed to establish the relationship between theory and practice making learning more meaningful.
\end{abstract}

Keywords: Professional and Technological Education. PROEJA. Learning. Active Methodologies.

\title{
RESUMEN
}

Este artículo tiene por objetivo general analizar las dificultades y potencialidades del desarrollo de metodologías activas en el Programa Nacional de Integración de la Educación Profesional con la Educación Básica en la modalidad de Educación de Jóvenes y Adultos (EJAEPT). Este estudio fue desarrollado con dos clases del curso Técnico en Agroindustria ofertado en el campus Camboriú del Instituto Federal Catarinense (IFC). Así, se definió el abordaje de esa investigación como cualitativa y se realizaron observaciones participantes de actividades pedagógicas desarrolladas con dos clases. Las anotaciones y relatos de estas observaciones fueron organizadas para realizar el análisis documental. Se concluyó que el perfil de los estudiantes de las clases A y B exigió estrategias de enseñanza-aprendizaje diferentes, así como tiempos y ritmos de enseñanza-aprendizaje distintos. En este proceso de docencia con ambas clases se observa que las dificultades de aprendizaje aparecen vinculadas a la dificultad de visualizar los conocimientos teóricos en la práctica. En ese sentido las metodologías activas posibilitaron que se estableciera la relación entre teoría y práctica haciendo el aprendizaje significativo.

Palabras Clave: Educación Profesional y Tecnológica. PROEJA. Aprendizaje. Metodologías Activas.

\section{INTRODUÇÃO}

O PROEJA ${ }^{1}$ se destina a oferecer oportunidade de estudos para para jovens e adultos

\footnotetext{
${ }^{1}$ Conforme Decreto no 5.840 de 13 de junho de 2006 (BRASIL, 2006), PROEJA é a abreviação de Programa Nacional de Educação Profissional com a Educação Básica na Modalidade de Jovens e Adultos. Para designar esse programa, neste artigo serão adotadas as duas siglas sinônimas: EJAEPT e PROEJA.
} 
ao ensino fundamental ou médio, considerando em sua organização curricular as condições de vida e de trabalho do aluno (IFC, 2016). Essa política visa fomentar a Educação de Jovens e Adultos (EJA) em articulação com a Educação Profissional. Nesse sentido assume-se a “[...]formação integral dos sujeitos, como forma de compreender e se compreender no mundo" (BRASIL, 2007, p. 43) a partir de uma proposta curricular que proporcione condições para que todos os cidadãos e cidadãs, independentemente de sua origem socioeconômica, tenham acesso, permanência, sucesso e progressão na educação pública, gratuita, unitária e com qualidade (BRASIL, 2007).

O PROEJA, historicamente, se constitui em um desafio para o professor, à medida que o estudante que chega ao PROEJA teve sua trajetória escolar interrompida, na maioria das vezes, por motivos que envolvem questões sociais e culturais complexas. Os cursos de EJA, em geral, são noturnos e os professores, na maior parte das vezes, encontram em sala estudantes já cansados de um extenso dia de trabalho, sem contar que alguns deles já estão há mais de 30 anos longe dos bancos escolares. No entanto, os estudantes que chegam ao PROEJA têm, em geral, um vasto conhecimento sobre a vida e sobre a prática de algumas atividades específicas, requerendo um ambiente escolar acolhedor e confortável, que valorize as experiências de cada um e onde o mesmo sinta confiança para compartilhar suas vivências com o professor e o grupo, enriquecendo o processo de aprendizagem de todos.

A EJAEPT, a qual encontra-se atualmente regulamentada pelo Decreto 5.840, que data de 13 de julho de 2006 (BRASIL, 2006), e pelo Documento Base instituído pelo MEC para orientar o Programa Nacional de Integração da Educação Profissional com a Educação Básica na Modalidade de Educação de Jovens e Adultos (BRASIL, 2007), abrange cursos que proporcionam formação profissional com escolarização para jovens e adultos, buscando a superação da dualidade entre trabalho manual e intelectual. Os cursos voltados à EJA podem ser ofertados de modo integrado ao ensino técnico, se configurando um desafio ainda mais complexo dentro deste contexto, já que, em um curto espaço de tempo, objetiva ensinar ao estudante a base de uma nova profissão e a formação básica de nível médio, como é o caso do Curso Técnico em Agroindústria do Instituto Federal Catarinense (IFC), Campus Camboriú. Diante das dificuldades e potencialidades do trabalho pedagógico na Educação de Jovens e Adultos, acredita-se que a educação, através do professor, precisa motivar, surpreender, cativar o estudante, considerando que a aprendizagem só acontece quando este encontra significado e desafio nas atividades propostas. 
Ser protagonista de seu próprio aprendizado permite ao estudante autodesenvolvimento, motivação e superação dos desafios inerentes ao processo de aprendizagem. Assim, as metodologias ativas se configuram uma alternativa ao "ensino bancário" tradicionalmente tão utilizado na educação brasileira e criticado por Paulo Freire (FREIRE, 2002), que relata que somente desenvolvendo no estudante a "curiosidade epistemológica" é possível alcançar o conhecimento. Aulas com atividades gamificadas, utilizando gincanas de perguntas e respostas, atividades de construção de conhecimento em grupo, dramatização, aprendizagem baseada em problemas, aulas práticas, entre outros, têm sido utilizadas com sucesso para despertar o interesse e tornar o processo de aprendizagem mais dinâmico. Dessa forma, este trabalho tem como tema de pesquisa metodologias de ensino ativas como instrumentos para a superação das dificuldades de aprendizagem dos estudantes da EJA.

A partir dessa temática define-se como objetivo analisar as dificuldades e potencialidades do desenvolvimento de metodologias ativas no Técnico em Agroindústria do IFC-Campus Camboriú .

Para responder ao que está posto acima apresenta-se a Introdução (1), Fundamentação teórica (2), Metodologia de pesquisa (3), Análise e discussão dos dados (4) e, por fim, a Conclusão (5).

\section{FUNDAMENTAÇÃO TEÓRICA}

Nesta seção são apresentados os fundamentos teóricos desta pesquisa a partir de três itens que articulam os princípios da EJAEPT (2.1), com o perfil de seus estudantes da EJA (2.2) e as metodologias ativas nesse contexto (2.3).

\subsection{A EDUCAÇÃO DE JOVENS E ADULTOS NA EDUCAÇÃO PROFISSIONAL E TECNOLÓGICA}

A EJAEPT é mais que um projeto educacional, ela é um poderoso instrumento de resgate da cidadania de toda uma imensa parcela de brasileiros excluídos do sistema escolar, por problemas dentro e fora da escola (BRASIL, 2007). O direito de acesso à educação aos jovens e adultos está garantido na Lei de Diretrizes e Bases da Educação, no artigo 37 (LDB/1996) que prevê a modalidade EJA como um "instrumento para a educação e a aprendizagem ao longo da vida". 
A EJAEPT, então, tem seu projeto educacional fundado na

Integração entre trabalho, ciência, técnica e tecnologia, humanismo e cultura geral com a finalidade de contribuir para o enriquecimento científico, cultural, político e profissional como condições para o efetivo exercício da cidadania (BRASIL, 2007).

Buscando a superação da dualidade entre trabalho manual e intelectual, os cursos do PROEJA proporcionam formação profissional com escolarização para jovens e adultos (IFC, 2016). Moura e Henrique (2012, p. 116) citam que um “[...] dos grandes desafios do Proeja é integrar três campos da educação que historicamente não estão muito próximos: o ensino médio, a formação profissional técnica de nível médio e a educação de jovens e adultos”. Portanto, uma das finalidades mais significativas de um curso técnico deve ser a capacidade de proporcionar educação básica sólida, em vínculo estreito com a formação profissional, ou seja, a formação integral do educando. A formação assim pensada contribui para a integração social do educando, o que compreende o mundo do trabalho sem resumir-se a ele, assim como compreende a continuidade de estudos (BRASIL, 2007). Na Educação Profissional Tecnológica (EPT), o foco do ensino é direcionado ao saber-fazer de uma atividade específica, sendo todo o processo concentrado, em um intervalo de tempo relativamente curto.

No documento base, o Ministério da Educação (BRASIL, 2007) faz uma importante reflexão:

\begin{abstract}
A educação profissional e tecnológica comprometida com a formação de um sujeito com autonomia intelectual, ética, política e humana exige assumir uma política de educação e qualificação profissional não para adaptar o trabalhador e prepará-lo de forma passiva e subordinada ao processo de acumulação da economia capitalista, mas voltada para a perspectiva da vivência de um processo crítico, emancipador e fertilizador de outro mundo possível (BRASIL, 2007, p. 32).
\end{abstract}

Assim, a oferta organizada se faz orientada a proporcionar a formação de cidadãos-profissionais capazes de compreender a realidade social, econômica, política, cultural e do mundo do trabalho, para nela inserirem-se e atuarem de forma ética e competente, técnica e politicamente, visando à transformação da sociedade em função dos interesses sociais e coletivos, especialmente os da classe trabalhadora. De acordo com Barbosa e Moura (2013), a EPT requer aprendizagem significativa, contextualizada e que favoreça o uso intensivo de recursos de inteligência, gerando habilidades em resolver problemas e conduzir projetos nos diversos segmentos do setor produtivo. 
Neste contexto, conhecer o perfil dos estudantes da EJAEPT é fundamental para promover processos de ensino-aprendizagem significativos. Portanto, no próximo item discutem-se as relações entre projeto pedagógico de curso, perfil do estudante EJAEPT e estratégias pedagógicas.

\subsection{O ESTUDANTE DA EDUCAÇÃO DE JOVENS E ADULTOS}

Para delinear o projeto pedagógico do curso e para a tomada de decisão dos instrumentos didáticos a serem utilizados pelo professor, é muito importante conhecer a situação de vida e de trabalho dos jovens e adultos a fim de despertar interesse e estimular o estudante a concluir o curso escolhido (COSTA et al., 2007). O próprio Ministério da Educação reconhece os estudantes da modalidade EJAEPT como “[...] sujeitos marginais ao sistema, com atributos sempre acentuados em consequência de alguns fatores adicionais como raça/etnia, cor, gênero, entre outros" (BRASIL, 2007, p. 11).

Assim, os estudantes que retornam para a escola através da EJAEPT podem ser considerados heterogêneos, no entanto, compartilham uma peculiaridade, que é ter tido sua trajetória escolar interrompida (COSTA et al., 2007). Nesse contexto, a trajetória do ensino de jovens e adultos no Brasil vem passando por diversas transformações, sendo que, atualmente, nota-se que o objetivo não é só oferecer ao indivíduo a formação básica, e sim, buscar a profissionalização, isto é, proporcionar oportunidades educacionais que integrem a última etapa da educação básica à formação profissional (COSTA et al., 2007).

O público que compõe a educação de jovens e adultos, em sua maioria, são sujeitos que retornam para a escolarização formal em idade adulta, em busca de melhores condições de vida, estudantes que "carregam trajetórias perversas de exclusão social, vivenciam trajetórias de negação dos direitos mais básicos à vida, ao afeto, à alimentação, moradia, ao trabalho e à sobrevivência” (ARROYO, 2005, p. 14). Mesmo após uma trajetória social repleta de dificuldades e incertezas, retornam à escola à procura de alfabetização, oportunidades profissionais e ascensão social.

Um estudo realizado em Fortaleza, por Costa et al. (2007), o qual avaliou o perfil de estudantes do PROEJA de um curso técnico em refrigeração e telecomunicações, concluiu que 69,39\% dos estudantes iniciaram e concluíram o ensino fundamental em escolas públicas, fato este que pode muito bem ser explicado pelo perfil socioeconômico. Este mesmo estudo demonstrou que a quantidade de estudantes que atribuem às faltas e/ou ao abandono do curso 
motivos de trabalho é bastante expressiva, sendo que muitos relatam que enfrentam muitas dificuldades em acompanhar o ritmo das disciplinas ministradas, o que conduz ao questionamento acerca das metodologias utilizadas, se estão adequadas ao público-alvo.

Demonstra-se que é salutar a discussão de estratégias pedagógicas que permitam a integração e o êxito dos estudantes no processo de ensino-aprendizagem, para que encontrem estímulo para frequentar as aulas e ainda possam aprender conteúdos significativos, mediados por metodologias que envolvam a participação e facilitem o aprendizado, já que também faz-se notória a dificuldade ocasionada pelo cansaço das atividades laborais exercidas pelos estudantes e, ainda, por um horário de trabalho mais exaustivo, que os impedem, muitas vezes, de comparecer às aulas (COSTA et al., 2007).

Desta forma, apresenta-se no próximo item as metodologias ativas como alternativa para o planejamento de atividades pedagógicas na EJAEPT.

\subsection{METODOLOGIAS ATIVAS DE ENSINO-APRENDIZAGEM}

Kuenzer (2006) reflete que, para que diferentes sujeitos sociais possam alcançar a aprendizagem, é necessária uma linguagem e métodos de ensino que lhes permitam a compreensão e a elaboração teórica de sua própria prática, o que exigirá dos professores a reflexão em torno de estratégias mais adequadas para utilizar em sala de aula. Para a elaboração das estratégias deve ser considerado também que os jovens e adultos estudam e trabalham, portanto, necessária se faz a organização dos tempos e espaços adequados a cada realidade. Baseado no depoimento de estudantes da EJAEPT, Farai e Assis (2014) comprovam que existe a clara reivindicação da criação de espaços reais de aprendizagem que deem conta das particularidades do estudante, como tempos diferenciados de vida, percurso de vulnerabilidade no quadro empregatício e cultura e identidades próprias.

Diesel, Baldez e Martins (2017) refletem que, enquanto o método tradicional de ensino prioriza a transmissão de conteúdos e tem sua centralidade na figura do docente, no método participativo, os estudantes ocupam o centro das ações educativas e o conhecimento é construído de forma colaborativa. O documento base sobre o PROEJA (BRASIL, 2007) traz à tona a necessidade de investigar as reais necessidades de aprendizagem dos sujeitos estudantes, entendendo como articular os conhecimentos prévios produzidos no seu estar no mundo àqueles disseminados pela cultura escolar, nessa relação de múltiplos aprendizados.

É importante salientar que os estudantes dessa modalidade possuem perfil diferenciado 
em relação à vivência e à faixa etária, carregando um nível de aprendizagem representado por saberes gestados na sua prática social, que necessitam ser propostos nos conteúdos de cada disciplina. Partindo desse pressuposto, caberá ao professor motivar e estimular os jovens e adultos com vistas à sua permanência em sala de aula, contextualizando os conteúdos de aprendizagem com a sua realidade de vida. Discutindo a esse respeito, Santos (2007), em um estudo acerca da permanência de jovens e adultos no ambiente escolar, afirma que é importante pensar a condução do trabalho docente nas salas da EJA. Na concepção de Santos (2007), se ratifica o fato de que recai sobre o trabalho docente a responsabilidade de criar uma dinâmica, uma linha metodológica que motive o estudante, sendo que Farai e Assis (2014) destacam a necessidade de uma formação específica para os professores que lecionam nessa modalidade, garantindo que os mesmos estejam preparados para os desafios a serem superados.

De acordo com Selbach (2010), é essencial que os professores do Ensino de Jovens e Adultos percebam que têm em suas mãos um desafiador conhecimento sobre a vida e sobre a natureza, que requer mais discussões que discursos, mais reflexões que memorizações. Nesse sentido, o docente precisa tornar o âmbito escolar dinâmico e comunicativo, para que os discentes se sintam confortáveis e ocorra o compartilhamento de informações, tanto individual quanto coletivo, proporcionando a estruturação dos saberes. Desse modo, o discente torna-se participante ativo no processo de ensino e aprendizagem, num espaço de diálogo harmonizado pelo professor, visto que, segundo Silva (2012), "ele disponibiliza domínios de conhecimento de modo expressivamente complexo e, ao mesmo tempo, uma ambiência que garante a liberdade e a pluralidade das expressões individuais e coletivas" (SILVA, 2012, p. 223).

Estudiosos como Freire (1996), Rogers (1973) e Novack (1996), entre outros, enfatizam, há muito tempo, a importância de superar a educação bancária, tradicional e focar a aprendizagem do aluno, envolvendo-o, motivando-o e dialogando com ele. Segundo Moran (2007), a educação tem que surpreender, cativar, conquistar os estudantes a todo momento. A educação precisa encantar, entusiasmar, seduzir, apontar possibilidades e realizar novos conhecimentos e práticas. O conhecimento se constrói a partir de constantes desafios, de atividades significativas, que excitem a curiosidade, a imaginação e a criatividade.

Segundo Freire (1996), o diálogo entre educador e educando é o aspecto fundamental para a problematização de situações reais vividas pelo educando. Nesse sentido, os Três 
Momentos Pedagógicos propostos por Delizoicov, Angotti e Pernambuco (2011) permitem a construção do conhecimento junto ao educando, criando espaço para o diálogo e respeitando a velocidade individual de aprendizagem dos estudantes.

Assim, as metodologias ativas, em que o aluno passa a ser protagonista de seu próprio processo de ensino e aprendizagem, são pontos de partida para avançar para processos mais avançados de reflexão, de integração cognitiva, de generalização, de reelaboração de novas práticas. Com base nesse entendimento, as metodologias ativas promovem um processo que visa a estimular a autoaprendizagem e a curiosidade do estudante para pesquisar, refletir e analisar possíveis situações para tomada de decisão.

Para discutir estratégias pedagógicas baseadas em metodologias ativas, apresentam-se os seguintes autores: Muenchen (2010), Muenchen e Delizoicov (2012), Leite e Esteves (2005), Ketamo (2007), Courtney (2003), Gramigna (2007) e, por fim, Delizoicov (2008).

De acordo com Muenchen (2010) e Muenchen e Delizoicov (2012), "os Três Momentos Pedagógicos" podem ser utilizados para a construção de programas escolares e currículos em um processo contínuo de ação e reflexão. Os três momentos pedagógicos se dividem em:

a) problematização inicial: o educador lança problematizações iniciais de um tema significativo ao educando, para que o mesmo exponha suas opiniões e perceba a necessidade de adquirir novos conhecimento;

b) organização do conhecimento: o professor atua como mediador entre o educando e o conhecimento a ser estudado;

c) aplicação do conhecimento: retomam-se as problematizações iniciais para avaliar o conhecimento e inserir novos contextos que podem ser interpretados de acordo com o novo conhecimento (DELIZOICOV, 2008).

Dentro das metodologias ativas, Leite e Esteves (2005) definem a Aprendizagem Baseada em Problemas (PBL) como uma abordagem centrada no estudante, que os capacita a realizar pesquisas, a integrar teoria e prática e a aplicar conhecimentos e habilidades inerentes à sua área de conhecimento para desenvolver uma solução viável para um problema definido. Courtney (2003) corrobora com essa ideia, afirmando que a imaginação dramática está no centro da criatividade humana e, assim sendo, deve estar no centro de qualquer forma de educação que vise ao desenvolvimento das características essencialmente humanas, auxiliando na resolução dos problemas. 
A utilização de jogos educativos também é uma forma de metodologia ativa que pode ser utilizada, sendo que o termo "jogo" é definido por Gramigna (2007) como uma atividade espontânea, realizada por mais de uma pessoa, regida por regras que determinam quem vencerá. Segundo Ketamo (2007), o uso de jogos educativos explora a maneira como o estudante utiliza seus conhecimentos prévios diante de um desafio (partida do jogo), ou seja, proporciona o 'aprender fazendo', e é este o eixo central de um jogo educativo: fazer com que o estudante coloque em prática suas competências. O jogo dá liberdade ao estudante de aprender de maneira exploratória através dos seus próprios erros, exigindo um pensamento reflexivo para compreender esses erros e solucioná-los com o objetivo de avançar no jogo.

A partir das considerações da fundamentação teórica apresentada nos itens acima, definiu-se a metodologia de pesquisa que será apresentada no próximo item.

\section{METODOLOGIA DE PESQUISA}

Segundo Lüdke e André (1986), o que determina a escolha da metodologia a ser utilizada em um estudo é a natureza do problema. Diante dessa premissa, Lessa (2008) determina que, para que a realidade complexa que caracteriza a escola seja estudada com rigor científico, é necessária a utilização dos subsídios encontrados na vertente qualitativa de pesquisa, considerando que a vida humana é uma atividade interativa e interpretativa, realizada pelo contato das pessoas, e que o ser humano em si não é passivo, interpretando continuamente o mundo em que vive.

Lessa (2008) cita também que os estudos qualitativos são importantes, pois são capazes de proporcionar a real relação entre teoria e prática, oferecendo ferramentas eficazes para a interpretação das questões educacionais. Segundo André (2005), não são as técnicas o que define o tipo de estudo e, sim, o conhecimento que advém dele. Assim sendo, esta pesquisa qualitativa se configura como um estudo de caso etnográfico exploratório, ou seja, "um estudo em profundidade de um fenômeno educacional, com ênfase na sua singularidade e levando em conta os princípios e os métodos da etnografia”, conforme mencionado por André (2005, p. 19).

Assim, esse estudo de caso foi realizado com aproximadamente quarenta estudantes, em duas turmas do Curso Técnico em Agroindústria do IFC-Campus Camboriú, durante o ano de 2018, dentro das disciplinas de Estágio em Docência na Educação Profissional I e II. Para

fins de análise, as turmas serão nomeadas como turma A e turma B. A intervenção com a 
turma A foi realizada no primeiro semestre de 2018. Nesse período a turma encontrava-se no segundo ano do curso. Já a turma B, na qual a intervenção foi realizada no segundo semestre de 2018, encontrava-se no primeiro ano do curso técnico em questão, sendo que as atividades foram realizadas dentro do período letivo das disciplinas Tecnologia de Carnes I (no caso dos estudantes do $1^{\circ}$ ano de curso) e Tecnologia de Carnes II (no caso dos estudantes do $2^{\circ}$ ano do curso). A escolha das disciplinas para a realização desse estudo foi feita em função da pesquisadora que realizou as atividades práticas, sendo que a mesma é bacharel em Medicina Veterinária.

Esse estudo utilizou duas técnicas para a coleta de dados: a observação participante e a análise documental. A observação participante pode ser definida como "[...] um processo pelo qual um pesquisador se coloca como observador de uma situação social, com a finalidade de realizar uma investigação científica" (MINAYO, 2015, p.70). Nesse estudo, a observação ocorreu de forma direta, estando a pesquisadora envolvida no processo de ensino-aprendizagem.

O trabalho foi conduzido da mesma forma com as duas turmas, computando um total de 20 horas com cada turma, sendo 12 horas de interação direta e 8 horas de observação dos estudantes em aula com o professor supervisor. Ao longo das 12 horas de interação direta, foram utilizadas metodologias ativas de ensino, colocando o estudante como protagonista de seu processo de aprendizagem. As metodologias utilizadas nas intervenções incluíram: os Três Momentos Pedagógicos propostos por Delizoicov (2008), dramatização de uma situação real, problematização, prática inclusiva, dinâmicas em grupo, estudo de caso prático e gincana de perguntas e respostas. Dessa forma, as propostas de intervenção pedagógica também foram fundamentadas em autores, como Ketamo (2007), que discutem a importância da imaginação e do jogo na aprendizagem focando na atividade prática, e Leite e Esteves (2005), que apresentam a aprendizagem baseada em problemas.

Com a turma A desenvolveram-se os conteúdos "Aspectos Higiênicos da Carne" e "Boas Práticas de Manipulação", utilizando os três momentos pedagógicos, problematização, dramatização, dinâmicas em grupo e prática inclusiva. Já com a turma B desenvolveram-se os conteúdos "Boas Práticas de Manipulação" e "Obtenção Higiênica de Pescados", utilizando problematização, prática inclusiva, dramatização de uma situação real, dinâmicas em grupo, estudo de caso prático e gincana de perguntas e respostas.

Para a análise documental, foram utilizados como fonte de dados para reflexão os 
relatórios de estágio em docência em ensino tecnológico I e II, em que foram consideradas as vivências da estagiária, a qual estava imersa no processo, além de feedbacks dos estudantes e do professor supervisor que acompanhou as atividades, além de avaliação das percepções durante as 8 horas de observação realizada em cada turma. Também foram utilizadas as avaliações da aprendizagem realizadas ao fim de cada atividade para trazer clareza sobre o resultado do processo de ensino e aprendizagem. Anteriormente ao início das atividades, o professor supervisor passou informações relevantes sobre a história de vida e o perfil de cada estudante, sendo essas informações levadas em conta durante a escolha e condução das atividades, assim como durante o momento de reflexão sobre os dados coletados.

Após a realização das observações, as anotações foram organizadas para a análise e, após reflexões que buscaram articular dados empíricos com a fundamentação teórica, construiu-se o texto do próximo item com os resultados e discussão da pesquisa.

\section{RESULTADOS E DISCUSSÃO}

Nesta seção, apresenta-se dois itens que tratam da análise das atividades com as turma A (4.1) e B (4.2).

\subsection{REFLEXÕES SOBRE A INTERVENÇÃO PEDAGÓGICA COM A TURMA A}

A primeira intervenção com a turma A foi realizada através da metodologia dos Três Momentos Pedagógicos a partir do conteúdo sobre os aspectos higiênicos relacionados à carne. Na primeira parte da aula, em que realizou-se a problematização inicial, percebeu-se que a atividade em grupo, a qual consistia responder perguntas básicas e simples acerca do assunto, foi mais complexa para os estudantes do que o esperado. Claramente os estudantes tiveram dificuldades para mobilizar seus conhecimentos prévios sobre o conteúdo desenvolvido, assim, foi necessário ocupar mais tempo da aula com essa atividade e com debates em pequenos grupos para estimular que os estudantes buscassem experiências e conhecimento prévio acerca das perguntas.

Segundo Delizoicov e Angotti (1990), mais do que simples motivação para se introduzir um conteúdo específico, a problematização inicial visa à ligação desse conteúdo com situações reais que os estudantes conhecem e presenciam, mas que não conseguem interpretar completa ou corretamente porque ainda não dispõem de conhecimentos científicos suficientes sobre o conteúdo. Já segundo Lopes (2009), esse momento da problematização é 
um dos momentos mais ricos do planejamento da aula, pois a partir desse passo se define o que realmente precisa ser estudado e aprofundado, sendo que, nesse momento, o estudante deve receber várias informações para que possa estabelecer relações entre o conhecimento científico e a sua realidade.

No segundo momento pedagógico, organização do conhecimento, foi utilizado quadro branco e recurso audiovisual dinâmico com imagens e exemplos do cotidiano dos alunos, promovendo o interesse dos alunos e tornando o conhecimento aplicável. Além disso, para aprofundar os conhecimentos dos estudantes sobre contaminação bacteriana, foram apresentadas placas de Petry $^{2}$ com colônias das principais bactérias contaminantes da carne e lâminas com as formas microscópicas destas bactérias para visualização ao microscópio, para que os alunos pudessem visualizar e entender melhor o conteúdo. A visualização macroscópica e microscópica das colônias bacterianas tornou a aula dinâmica, trazendo curiosidade e empolgação aos estudantes.

No terceiro momento pedagógico, de aplicação de conhecimentos das aulas de 'Boas Práticas na Manipulação de Carnes', estava prevista somente a aplicação de um check list de boas práticas e instalações no abatedouro. Entretanto, devido à dificuldade de entendimento dos estudantes sobre a existência de bactérias sobre as superfícies no preparo do alimento, considerando que esse é um assunto distante da realidade da maioria, optou-se por incluir nessa aula uma prática de coleta de $s w a b^{3}$ nas superfícies no abatedouro; assim, os estudantes puderam colocar a "mão na massa", ou seja, eles mesmos coletaram as amostras de locais em que gostariam de saber se havia contaminação bacteriana, colocando a amostra na placa de Petry para, posteriormente à incubação ${ }^{4}$, poder observar o crescimento que ocorreu. Essa atividade dentro do momento de aplicação de saberes enriqueceu enormemente a intervenção pedagógica como um todo e permitiu a construção de um aprendizado mais consistente e uma significativa compreensão dos conteúdos.

Ainda dentro do contexto da Aplicação de Conhecimentos, foi realizada uma vivência de aplicação de tinta em uma aluna voluntária vendada, para que a mesma fizesse a lavagem de mãos. Essa atividade pedagógica foi desenvolvida a partir de uma discussão que aconteceu em sala de aula, sobre a questão da problemática que envolve a proibição de unhas compridas

\footnotetext{
${ }^{2}$ Placas de Petry: recipiente cilíndrico, achatado, de vidro ou plástico utilizado para cultura de microrganismos.

${ }^{3} \boldsymbol{S w a b}$ : utensílio estéril, semelhante a um cotonete que tem a funcionalidade de coletar amostras clínicas.

4 Incubação: processo laboratorial por meio do qual se cultivam microrganismos a uma determinada temperatura, com a finalidade de estudar e/ou facilitar o seu desenvolvimento.
} 
e pintadas para a manipulação de alimentos. A dinâmica permitiu aos estudantes a compreensão dos motivos dessa proibição, já que na demonstração a estudante não conseguiu retirar toda a tinta debaixo de suas unhas. Esta vivência atingiu seu propósito, criando um ambiente descontraído, que permitiu um maior impacto sobre os estudantes e o desenvolvimento de um aprendizado significativo e contextualizado. Segundo Delizoicov e Angotti (1990), o momento de aplicação de conhecimentos destina-se, sobretudo, a abordar sistematicamente o conhecimento que vem sendo incorporado pelo estudante, para analisar e interpretar tanto as situações iniciais que determinaram o seu estudo, como outras situações que não estejam diretamente ligadas ao motivo inicial, mas que são explicadas pelo mesmo conhecimento. Com isso, pretende-se que, "dinâmica e evolutivamente", o estudante perceba que o conhecimento, além de ser uma construção historicamente determinada, está acessível a qualquer cidadão e, por isso, deve ser apreendido, para que possa fazer uso dele.

Krasilchik (1996) relata que, quanto mais as experiências educativas se assemelharem às futuras situações em que os alunos deverão aplicar seus conhecimentos, mais fácil se tornará a concretização do aprendizado. Zabala (1998) corrobora com essa ideia, citando que o professor tem a importante função de planejar atividades práticas para facilitar a compreensão dos conteúdos teóricos aos alunos, estimulando-os a questionar, responder, observar, explorar, analisar, comparar e compreender a situação problema, levando ao desenvolvimento de novos conhecimentos, uma vez que o acesso ao conhecimento novo ocorre a partir do pré-existente.

Nesta turma, havia um aluno com deficiência, o qual foi motivado a realizar a atividade de coleta de swab e leitura da placa de Petry e deu um excelente feedback sobre como sentiu-se incluído e capaz. Freire (2011) defende a ideia de que só é possível uma prática educativa dialógica por parte dos educadores se estes acreditarem no diálogo como um fenômeno humano capaz de mobilizar o refletir e o agir dos homens e mulheres. E para compreender melhor essa prática dialógica, o autor acrescenta que o diálogo não pode reduzir-se ao ato de um sujeito depositar ideias no outro, nem tampouco tornar-se simples troca de ideias a serem consumidas pelos permutantes.

Quanto mais o professor compreender a dimensão do diálogo como postura necessária em suas aulas, maiores avanços estará conquistando em relação aos alunos, pois, desse modo, eles se sentirão mais curiosos e mobilizados para transformarem a realidade. Lopes (2009) cita que, quando o professor atua nessa perspectiva, ele não é visto como um mero 
transmissor de conhecimentos, mas como um mediador, alguém capaz de articular as experiências dos alunos com o mundo, levando-os a refletir sobre seu entorno, assumindo um papel mais humanizador em sua prática docente.

Dal Bem (2011) define o professor do PROEJA como um agente que seleciona saberes, produz estímulos, suscita motivação, estabelece sentido e potencializa vínculos afetivos fortes no processo de aprendizagem. Esses vínculos afetivos geram relações interpessoais estreitas, dialógicas, com uma marca de cumplicidade recíproca. Através dessa fala é possível entender a importância do estágio aqui relatado para formação da autora desse trabalho como professora, permitindo a vivência prática e reflexiva do papel pessoal da pesquisadora como educadora na promoção da qualidade do ensino voltado à Educação de Jovens e Adultos, a qual é inspiração na caminhada docente.

\subsection{REFLEXÕES SOBRE A INTERVENÇÃO PEDAGÓGICA COM A TURMA B}

Dentro da intervenção realizada com a turma $\mathrm{B}$, desde o primeiro dia, apesar das diferenças de idade e, consequentemente, de tempo sem estudo e também de perfil, foi perceptível o bom nível de conhecimento prévio e um comportamento bastante maduro e respeitoso com as diferenças entre os estudantes. Além disso, os mesmos mostraram-se abertos a novas experiências e metodologias ativas, o que facilitou muito o trabalho e tornou a experiência ainda mais enriquecedora e especial. A partir disso, ficou claro que o planejamento inicial poderia ser adaptado, utilizando atividades com um nível mais desafiador aos alunos e provocando discussões mais ricas, oportunizando espaço para que os alunos contribuíssem com os seus conhecimentos, permitindo assim aperfeiçoar e tornar aplicável esse aprendizado na realidade individual de cada um.

A perspectiva de Freire (1996) coincide com essa abordagem envolvendo o método participativo. De acordo com o educador, um dos grandes problemas da educação paira no fato de os alunos praticamente não serem estimulados a pensar com autonomia. Para amenizar esse contexto, Jófili (2002) sugere que o professor deve assegurar um ambiente dentro do qual os alunos possam reconhecer suas próprias ideias e refletir sobre elas, aceitando que outras pessoas expressem seus pontos de vista diferentes, mas igualmente válidos, e avaliando a utilidade dessas ideias em comparação com as teorias apresentadas pelo professor.

Dentro dessa lógica, a primeira aula foi conduzida sendo utilizada uma problematização inicial, e, na sequência da aula, após avanço construtivo no conteúdo, foi 
realizada uma gincana de perguntas e respostas em grupo, com perguntas em forma de problema, baseadas no assunto discutido anteriormente, para ajudar a fixar o conteúdo sobre obtenção higiênica de carnes e a avançar na discussão. O desempenho geral dos alunos na gincana foi excelente, e ficou perceptível o aproveitamento da aula, já que, mesmo cansados de um dia todo de trabalho, todos os alunos ficaram realizando a atividade até o fim da aula, de forma alegre e descontraída.

$\mathrm{Na}$ segunda aula, a qual foi realizada no abatedouro do campus, a predileção dos alunos por aulas fora do ambiente habitual de sala de aula ficou clara no entusiasmo e no feedback dos alunos. Foi novamente realizada a dinâmica de lavagem de mãos, já realizada com a turma A, com dois alunos voluntários realizando a atividade com olhos vendados. Essa atividade superou os objetivos propostos, na medida em que levantou inúmeras discussões relacionadas à prática profissional, como, por exemplo, a resistência dos manipuladores à proibição legal de se utilizar unhas compridas e pintadas, à lavagem de mãos, frequentemente realizada de forma inadequada, ao uso de luvas, entre outros. Delizoicov e Angotti (1990) refletem que durante atividades de problematização, como essa, a postura do educador deve se voltar mais para questionar e lançar dúvidas sobre o assunto que para responder e fornecer explicações.

Assim, a estratégia utilizada na segunda parte dessa aula foi aprendizagem baseada em problemas utilizando dramatização, ou seja, os alunos precisaram propor soluções para problemas reais de estrutura, fluxo e procedimento no abatedouro da instituição, representando um papel - proprietário, fiscal ou colaboradores do abatedouro. Como cada grupo representou um papel, essa atividade proporcionou ricas discussões e trouxe muitos elementos novos relacionados, incluindo as legislações vigentes na área, com dinamismo e descontração, proporcionando um aprendizado significativo. Dentro da tentativa de romper com algumas práticas que ainda privilegiam o exercício da repetição e da memorização nas escolas, Gasparin (2005) busca fundamentar uma proposta a qual considera e privilegia os conhecimentos que os alunos já trazem de sua experiência de vida, bem como estimula a aquisição de conhecimentos científicos, por meio da problematização.

Considerando essas reflexões, a terceira parte da aula, com a utilização de coleta de swab de superfícies para avaliar a contaminação bacteriana, foi incluída nesta aula, pois teve excelente impacto na realização do estágio I com a turma A. Inclusive, dentro do planejamento da proposta de estágio II com o professor supervisor, o mesmo solicitou que 
essa prática fosse repetida, considerando os ótimos feedbacks dos alunos e os resultados alcançados anteriormente com a mesma, visto a dificuldade de entendimento em geral dos alunos sobre a existência de bactérias sobre as superfícies no preparo do alimento.

Segundo Reeve (2009), o professor contribui para promover a autonomia do aluno em sala de aula, quando nutre os recursos motivacionais internos (interesses pessoais); oferece explicações racionais para o estudo de determinado conteúdo ou para a realização de determinada atividade; usa de linguagem informacional, não controladora; é paciente com o ritmo de aprendizagem dos alunos; e reconhece e aceita as expressões de sentimentos negativos dos alunos.

Assim, os alunos receberam as placas após incubação por 48 horas e puderam visualizar o crescimento bacteriano a olho nu. Essa visualização das colônias bacterianas e fúngicas causou surpresa, e foi comovente ver o interesse deles no assunto e o quanto a prática trouxe nova perspectiva a respeito do assunto. Trazer estas vivências práticas permitiu aos alunos a construção de um saber particular, baseado na própria visualização e sensação de fatos sobre os quais antes só tinham conhecimento breve e teórico. Após a visualização das placas e a discussão sobre o tema, a terceira aula seguiu com a problematização da questão higiênica especificamente na produção de pescados, repetindo-se a metodologia utilizada com sucesso na primeira aula. Durante essa aula, foi possível perceber que o assunto era desconhecido de grande parte dos alunos. Assim, vídeos sobre maricultura ${ }^{5}$ e ranicultura ${ }^{6}$ foram utilizados, ambos trazendo informações sobre o litoral catarinense, fato que causou aos alunos entusiasmo e curiosidade sobre o tema. A aula finalizou com a realização de um trabalho em grupo, com um problema relacionado ao tema da aula, para que os alunos discutissem soluções práticas e aplicáveis para o problema. Novamente, a turma se mostrou bastante interessada, propondo soluções inteligentes e criando uma rica discussão sobre o tema.

Considerando as experiências anteriores com turmas de PROEJA, essa turma se mostrou diferenciada, proporcionando aulas mais ricas e discussões mais profundas, o que gerou motivação extra durante o preparo e execução das atividades. Ficou visível a evolução de linguagem, argumentos e clareza dos alunos ao longo das aulas. Foi perceptível o quanto foram impactantes as vivências realizadas e a alegria que esse processo gerou, fazendo com

\footnotetext{
${ }^{5}$ Maricultura: considerada a aquicultura de águas marinhas, é o cultivo de organismos marinhos, que inclui a mitilicultura (cultivo de mexilhões), a ostreicultura (cultivo de ostras), a piscicultura (cultivo de peixes), entre outros.

${ }^{6}$ Ranicultura: parte da aquicultura que se refere à criação de rãs para a alimentação humana.
} 
que os alunos se sentissem valorizados e importantes em seu próprio processo de aprendizagem. Essa reflexão corrobora o pensamento de Freire (2011), que considera que a presença do diálogo nos momentos vividos em sala potencializa a participação do educando no processo de apropriação do conhecimento em todos os momentos, assim, o educador já não é o que apenas educa, mas o que, enquanto educa, é educado, em diálogo com o educando que, ao ser educado, também o educa. Ainda, Freire (2011) defende a ideia de que só é possível uma prática educativa dialógica, por parte dos educadores, se estes acreditarem no diálogo como um fenômeno humano capaz de mobilizar o refletir e o agir dos homens e mulheres.

\section{CONCLUSÃO}

Este artigo se propôs a discutir a Educação de Jovens e Adultos a partir de uma experiência pedagógica com duas turmas do Curso Técnico em Agroindústria ofertado no Campus Camboriú do Instituto Federal Catarinense (IFC). A partir dessa temática definiu-se como objetivo analisar as potencialidades do desenvolvimento de metodologias ativas nesse contexto.

Para atingir esse objetivo, foram organizados planejamentos pedagógicos com as turmas A e B, especialmente a partir da metodologia ativa proposta por Delizoicov (2008) denominada Três Momentos Pedagógicos, que se dividem em: a) problematização inicial; b) organização do conhecimento; c) aplicação do conhecimento. Ainda foram considerados no planejamento o uso da problematização, a partir de Leite e Esteves (2005), e do uso da imaginação, jogo e atividades práticas proposto por Ketamo (2007).

Após o planejamento, foram realizadas as intervenções pedagógicas que tiveram a duração de 20 horas com cada turma, sendo 12 horas de interação direta e 8 horas de observação dos estudantes em aula. A partir dessas intervenções, foram elaborados dois relatórios que foram analisados para este artigo. Portanto, considera-se este um estudo de caso etnográfico exploratório, em que se utilizou de observação participante e análise documental.

A partir das análises realizadas das intervenções pedagógica, pode-se concluir que as diferenças dos estudantes das turmas A e B exigiu estratégias de ensino-aprendizagem e tempos e ritmos de ensino-aprendizagem distintos. Nesse sentido, percebe-se a importância de o professor reconhecer as dificuldades dos estudantes durante o processo de ensino-aprendizagem para adaptar as estratégias e o ritmo das aulas às características dos 
estudantes. No relato das atividades pedagógicas, pode-se visualizar essa preocupação, bem como as mudanças realizadas para atender essas características.

Conclui-se também nesse processo de docência com ambas as turmas que as dificuldades de aprendizagem aparecem atreladas à dificuldade de visualizar os conhecimentos teóricos na prática. Nesse sentido as metodologias ativas possibilitaram que se estabelecesse a relação entre teoria e prática tornando a aprendizagem significativa, pois, como pode ser comprovado nos relatos, as turmas, a partir dessas metodologias, se colocaram de forma ativa no processo de ensino-aprendizagem.

Por fim, considera-se que o uso de metodologias ativas com jovens e adultos, nessa experiência, se mostrou enriquecedora para a aprendizagem dos estudantes, pois possibilitou uma prática educativa dialógica em que a aprendizagem ocorreu em um processo de interação entre sujeitos e entre sujeitos e objeto de ensino.

\section{REFERÊNCIAS}

ANDRÉ, M. E. D. A. Estudo de caso em pesquisa e avaliação educacional. Brasília: Liber Livro Editora, 2005.

ARROYO, M. G. Educação de Jovens-adultos: um campo de direitos e de responsabilidade pública. In: SOARES, L; GIOVANETTI, M. A. G C; GOMES, N. L.(Org.). Diálogos na educação de jovens e adultos. Belo Horizonte: Autêntica, 2005.

BARBOSA, E.F.; MOURA, D.G. Metodologias Ativas de Aprendizagem na Educação Profissional e Tecnológica. Revista Boletim Técnico do SENAC, Rio de Janeiro, v. 39, n 2. p. 48-67. Maio/agos. 2013.

BRASIL. Ministério da Educação. PROEJA: Programa Nacional de Integração da Educação Profissional com a Educação Básica na Modalidade de Educação de Jovens e Adultos. Documento Base. Brasília, agos. 2007. Disponível em:

http://portal.mec.gov.br/setec/arquivos/pdf2/proeja_medio.pdf. Acesso em: 25 agos. 2018.

BRASIL. Ministério da Educação: Decreto $n^{\circ}$ 5.840, de 13 de julho de 2006. Programa Nacional de Integração da Educação Profissional com a Educação Básica na Modalidade de Educação de Jovens e Adultos - PROEJA. Disponível em:

http://portal.mec.gov.br/setec/arquivos/pdf2/proeja_indigena.pdf. Acesso em: 30 agos.2018.

COSTA, F. L. M. et al.O perfil dos estudantes do proeja no CEFETCE: o que pensam e o que desejam. Fortaleza. 2007. Disponível em:

http://portal.mec.gov.br/setec/arquivos/pdf3/tcc_operfil.pdf. Acesso em: 25 agos. 2018.

COURTNEY, R. Jogo, teatro \& pensamento. São Paulo: Perspectiva, 2003. 
DAL BEM, E. J. Proeja: Desafios e Perspectivas Pedagógicas da Mediação. 2011. Trabalho de Conclusão de Curso. (Especialização em Educação Profissional Integrada à Educação Básica na Modalidade de Jovens e Adultos) - Universidade Federal de Santa Maria, Santa Maria, 2011.

DELIZOICOV, D. Didática Geral. Florianópolis: UFSC/EAD/CED/CFM, 2008. Disponível em:

http://nead.uesc.br/arquivos/Fisica/Fisica1/didatica/modulo/unidade_i_didatica_UFSC.pdf. Acesso em: 16 set.2018.

DELIZOICOV, D.; ANGOTTI, J. A. Metodologia do ensino de ciências. São Paulo: Cortez, 1990.

DELIZOICOV, D.; ANGOTTI, J. A. P.; PERNAMBUCO, M. M. C. A. Ensino de ciências: fundamentos e métodos. 4.ed. São Paulo: Cortez, 2011.

DIESEL A.; BALDEZ, A. L. S.; MARTINS, S. N. Os princípios das metodologias ativas de ensino: uma abordagem teórica. Revista Thema. v. 14, n 1. p. 268 a 288. 2017. Disponível em: http://revistathema.ifsul.edu.br/index.php/thema/article/viewFile/404/295. Acesso em: 14 set. 2018.

FARAI, D.S.A.; ASSIS, S.M. O Proeja Integrado à Educação Profissional: Desafios, Possibilidades e Práticas Docentes. Revista Holos. Ano 30, v. 02, p.123 a 133, 2014. Disponível em: http://www2.ifrn.edu.br/ojs/index.php/HOLOS/article/view/1968/809. Acesso em: 24 maio 2018.

FREIRE, P. Pedagogia da autonomia: saberes necessários à prática docente. São Paulo: Paz e Terra, 1996.

FREIRE, P. Pedagogia do Oprimido. Rio de Janeiro: Paz e Terra, 2011.

GASPARIN, J. L. Uma didática para a pedagogia histórico-crítica. 3 ed. Campinas: Autores Associados, 2005.

GRAMIGNA, M.R.M. Jogos de empresa. 2. ed. São Paulo: Editora Pearson, 2007.

INSTITUTO FEDERAL CATARINENSE. Projeto Pedagógico do Curso Proeja FIC Agroindústria Ensino Médio. 2016. Disponível em:

http://www.camboriu.ifc.edu.br/cet/wp-content/uploads/sites/7/2017/08/PPC_PROEJA_AGR OIND\%C3\%9ASTRIA_PRONTO.pdf. Acesso em: 25 agos. 2018.

JÓFILI, Z. Piaget, Vygotsky, Freire e a construção do conhecimento na escola. Educação: Teorias e Práticas. v. 2, n. 2, p. 191-208, dez 2002.

KETAMO, H., Learning by Teaching: A Case Study on Explorative Behaviour in an Educational Game, Network-Based Education, Finland, 2007.

KRASILCHIK, M. Educação ambiental na escola brasileira: passado, presente e futuro. 
Revista Ciência e cultura, ano 38, n.12, p. 1958- 1961, dez. 1996.

KUENZER, A. Z. As Mudanças no Mundo do Trabalho e a Educação: Novos desafios para gestão. In: FERREIRA, Naura S. Carapeto (org.). Gestão Democrática da Educação: Atuais tendências, novos desafios. 5. ed. São Paulo: Cortez, 2006.

LEITE, L.; ESTEVES, E. Ensino orientado para a Aprendizagem Baseada na Resolução de Problemas na Licenciatura em Ensino da Física e Química. In: SILVA, B.; ALMEIDA, L. (Eds.). Comunicação apresentada no VIII CONGRESSO GALAICO-PORTUGUÊS DE PSICOPEDAGOGIA. Braga: CIED - Universidade do Minho, p. 1751-1768, 2005.

LESSA, C. O. Um Apanhado Teórico-Conceitual Sobre a Pesquisa Qualitativa: Tipos, Técnicas e Características. v. 2, n. 3 (2008). Disponível em:

file://C:/Users/user/Downloads/Artigo\%20Pesquisa\%20Qualitativa.pdf. Acesso em: 15 set. 2018.

LOPES, R. C.S. A Relação Professor Aluno e o Processo Ensino Aprendizagem.

Diaadiaeducação. Portal Educacional do Estado do Paraná. Disponível em:

http://www.diaadiaeducacao.pr.gov.br/portals/pde/arquivos/1534-8.pdf. 2009. Acesso em: 25 agos. 2018.

LÜDKE, M.; ANDRÉ, M. E. D. A. Pesquisa em educação: abordagens qualitativas. São Paulo: EPU, 1986.

MINAYO, M.C.S. Pesquisa social: teoria, método e criatividade. Petrópolis: Vozes, 2015.

MORAN, J. M. Como utilizar a internet na educação. Revista Ciência da Educação. São Paulo, v.26, n. 2, 2007.

MOSCOVICI, S. Representações Sociais: investigações em psicologia social. Petrópolis: Vozes, 2004.

MOURA, D. H.; HENRIQUE, A. L S. PROEJA: Entre desafios e possibilidades. Campus EAD - Instituto Federal do Rio Grande do Norte. HOLOS, Ano 28, Vol 2 114, 2012. Disponível em: http://www2.ifrn.edu.br/ojs/index.php/HOLOS/article/viewFile/914/536. Acesso em: 25 agos. 2018.

MUENCHEN, C. A disseminação dos três momentos pedagógicos: um estudo sobre práticas docentes na região de Santa Maria/RS. 2010. . Tese (Doutorado em Educação Científica e Tecnológica) - Centro de Ciências em Educação, Universidade Federal de Santa Catarina, Florianópolis, 2010.

MUENCHEN, C.; DELIZOICOV, D. A construção de um processo didático-pedagógico dialógico: aspectos epistemológicos. Revista Ensaio: Belo Horizonte, v. 14, n. 3, p.199- 215, 2012.

REEVE, J. Why teachers adopt a controlling motivating style toward students and how they can become more autonomy supportive. Educational Psychologist. Hillsdale, v. 44, n. 3, p. 
$159-175,2009$.

ROGERS, C. R. Liberdade para aprender: uma visão de como a educação deve vir a ser. Belo Horizonte: Editora Interlivros, 1973.

SANTOS, M. A. M. T. A produção do sucesso na educação de jovens e adultos: o caso de uma escola pública em Brazilândia. 2007. Dissertação (Mestrado em Educação) - Faculdade de Educação, Universidade de Brasília, Brasília, 2007.

SELBACH, S. et al. Uma crônica para se pensar o ensino de Ciências. In: Ciências e didática. Petrópolis, RJ: Vozes, 2010. p.11-13.

SILVA, M. Sala de aula interativa: educação, comunicação, mídia clássica, internet. 6. ed. São Paulo: Edições Loyola, 2012.

ZABALA, Antoni. A prática educativa: como ensinar. Porto Alegre: Artmed,1998. 